Vol. 8, nº 1 | 2004

Varia

\title{
'A paradise for rascals': Colonialism, punishment and the prison in Hong Kong (1841-1898)
}

\section{Frank Dikötter}

\section{(2) OpenEdition}

Electronic version

URL: https://journals.openedition.org/chs/515

DOI: $10.4000 /$ chs. 515

ISSN: 1663-4837

Publisher

Librairie Droz

Printed version

Date of publication: 1 August 2004

Number of pages: $49-63$

ISBN: 2-600-00955-8

ISSN: 1422-0857

\section{Electronic reference}

Frank Dikötter, "'A paradise for rascals': Colonialism, punishment and the prison in Hong Kong (1841-1898)", Crime, Histoire \& Sociétés / Crime, History \& Societies [Online], Vol. 8, $n^{\circ} 1$ | 2004, Online since 25 February 2009, connection on 22 March 2022. URL: http://journals.openedition.org/chs/515 ; DOI: https://doi.org/10.4000/chs.515

This text was automatically generated on 22 March 2022.

(c) Droz 


\title{
'A paradise for rascals': Colonialism, punishment and the prison in Hong Kong (1841-1898)
}

\author{
Frank Dikötter
}

1 Victoria Gaol today is lost in a forest of soaring skyscrapers, steepled glass and concrete towers. While still in use to lock up sentenced criminals, the government in the new millennium is actively considering plans to convert the gaol into a tourist venue with shops and malls inspired by Covent Garden in London. Once a symbol of colonial power, a temple devoted to the rule of law, a monument of modernity that demarcated the island from its less civilised neighbours, this remnant of empire, like Government House or St John's Cathedral, has gradually faded into oblivion with Hong Kong's spectacular postwar growth and final return to Chinese sovereignty in 1997. Its history, however, can throw light on some of the tensions inherent in colonial enterprises. Although most archives were destroyed during World War II, a variety of surviving sources such as colonial correspondence, official reports and local newspapers, can be deployed to highlight two important strains which structured penal discourse and judicial practice in Hong Kong. While the new codes of law which appeared in Europe in the wake of the Enlightenment were based on different conceptions of subjectivity ${ }^{2}$, most nonetheless envisaged the person as a rational, responsible and equal individual. Opposition to a vision of equality was particularly pronounced in Hong Kong, as supporters of differential treatment pointed at the alleged differences in body and mind of Chinese criminals to justify their harsher punishment in comparison to Europeans. A marked diversity of views also existed on the purpose of punishment: the idea that legal sanctions should deter was widespread among both European and Chinese communities in Hong Kong, and both favoured a punitive approach towards the criminal. Advocates of the reformative aspect of the law, on the other hand, envisaged punishment as a morally transformative experience: the prison, in their view, should be a school in which criminals could be turned into obedient and productive subjects. The often bitter disputes between these two approaches are vividly illustrated by a history of punishment in nineteenth-century Hong Kong. The lash and 
the noose, foundations of deterrent punishment in Victoria Gaol, only gradually gave way to productive work and remission, exemplars of a faith in the reformative capacity of confinement. The meaning of the prison also changed drastically during this period. Prisoners were initially locked up together in common cells while awaiting transportation. Dissatisfaction with alternative modes of punishment, in particular transportation, branding and the use of a hulk ship, gradually turned the prison into a place of deterrent punishment for increasingly large numbers of criminals. Finally, as a new conception of the prison as a moral space of reformation emerged by the end of the century, criminals were classified into different groups, separated from each other and confined to single cells. This article analyses the gradual transformation of the prison from deterrence to reformation in the nineteenth century.

\section{The lash and the noose: the deterrent approach to punishment, 1841-1877}

2 Resistance against the more enlightened attitudes which developed in Europe is a common theme in the history of crime and punishment in Hong Kong. In a colonial site teeming with pirates, thieves and robbers, new ideas about humane treatment were considered to be misguided at best if not a direct threat to social order. The punitive approach is exemplified by the appointment of Captain William Caine, an officer with experience in the imposition of army discipline, as the first Chief Magistrate in Hong Kong on 30 April 1841. The colonial authorities in Hong Kong held that English law was unintelligible to the Chinese, and Caine resorted instead to the lash and the noose to assert his authority in preference to fines and imprisonment. His policy was given legal sanction when two ordinances were passed in 1844, giving the Supreme Court and the Magistrates the power to punish Chinese subjects according to the laws of China ${ }^{3}$.

3 As a result of the differential treatment of European and Chinese offenders, harsh floggings became increasingly common, giving rise to widespread concern both in Hong Kong and in England. A majority of Chinese offenders were flogged, the number of blows varying from twenty to a hundred. Floggings were carried out in public, as the criminal, with a label on his back written in Chinese, was conducted from the prison to the whipping stand ${ }^{4}$. Complaints about the frequency of floggings appeared as early as 1845, and 'disgusting exhibitions' were reported to occur almost on a daily basis. According to one witness account, a convict was tied up to the door-post of a public house next to a temporary police station, was stripped and had his back lacerated with the rattan. Contemporary critics relied on records of the Police Court to denounce the extent to which the rattan was deployed in Hong Kong: its use far surpassed that in most other countries, as Chinese subjects were publicly whipped for the most trifling offence. On 25 April 1846, for example, no less than fifty-four men were flogged and had their queues cut off for no other reason than being on the island without registration tickets 5 . Leaders of the Chinese community protested and John Bowring, later Governor of Hong Kong, raised the matter in Parliament, questioning the floggings ordered by the magistrates. A year later, as a Select Committee was appointed to look into the commercial relations with China, the habit of flogging and the cuttingoff of queues was also examined. The committee found that such practices were not sanctioned by any law of the colony and also discovered that poor Chinese were flogged or imprisoned for non-payment of fines and fees that were judged to be excessive ${ }^{6}$. 
Although corporal punishment appeared to have stopped after exposure before Parliament, floggings were resumed after fresh instructions from the Home Office. In October 1847, for instance, even members of the European community protested as old or sick beggars who represented no threat to social order were rounded up by the police, flogged and dumped in Kowloon?

Public floggings often attracted a great number of Chinese and a few Europeans, while in some cases no medical officers were present ${ }^{8}$. Wednesday was flogging day, and crowds would congregate in the square opposite the Harbour Master's office to witness the lash being applied to prisoners. 'Judging by the crowds of people of all nationalities who attended these scenes, it would appear as if they were looked upon as being by no means gruesome', commented one observer ${ }^{9}$. Flogging was considered the most viable way to put down crime, and only its excesses were condemned, especially the 'sanguinary and merciless despotism' with which it was practiced. The substitution of imprisonment for flogging, some argued, had not so much checked as encouraged crime by 'holding out at worst the prospect of house room, regular meals, and light labour to idle rogues and vagabonds', besides crowding the gaol ${ }^{10}$. The cutting-off of queues, including the shaving of the crown in order to prevent convicts from attaching a false tail, was only discontinued in 1848 on the express instructions of Governor Bonham.

5 Although the colonial authorities expressed great faith in the deterrent value of the rattan, a gaol was nonetheless erected in the early years of the colony for the punishment of offenders who were given a custodial sentence. Victoria Gaol was divided into two rows of six cells for European prisoners, the majority being sailors incarcerated for disobedience or disorderly conduct. The Chinese prisoners were confined in two buildings with a square open court in which they could air and wash themselves. Prison sentences varied in length from two days to four years. Chinese prisoners were supplied with rice and were occasionally given salt fish or vegetables, while pure water from the hills was also provided by a purveyor. Clothing and bedding was not made available by the prison authorities, except for a quantity of jackets, which were furnished to protect them from the cold during the winter. Many prisoners were sentenced to hard labour and employed mainly on the roads, calling out at 6.00 in the morning to return at 5.00 in the afternoon with the exception of Sundays. Labouring convicts and those in confinement were kept in leg irons ${ }^{11}$.

6 Incarceration, however, was not the preferred mode of punishment in Hong Kong. Besides the lash and the noose, the most popular sentence was transportation. European convicts were deported to Van Diemen's Land, also known as Tasmania, and later to South Africa. Chinese prisoners were sent to Labuan, a small island established by the Royal Navy off the coast of Borneo ${ }^{12}$. Transportation of prisoners was mutually arranged between different colonies, although it was increasingly criticised by the Home Office. In England, transportation declined in the 1840s to be entirely abolished in 1867 and replaced by imprisonment. In Hong Kong, practical difficulties in finding colonies willing to accept convicts also led to the gradual decline of transportation. Deportation to the Straits Settlement from Hong Kong, for instance, was interrupted in 1851, as the Grand Jury in Singapore objected to receiving Chinese convicts ${ }^{13}$. Transportation, moreover, was not found to work in practice, as convicts managed to return to the island. In 1854, to take a specific example, Chun Ayee, sentenced to fifteen years of transportation to Penang, was found at large in the colony. He was 
subsequently sentenced to a year's imprisonment with hard labour to be followed by transportation for life. Many Chinese criminals transported to Labuan also suffered medical problems: out of sixty Chinese convicts sent in August 1857, ten had died shortly after arrival due to illness contracted on board ${ }^{14}$.

7 As transportation declined, Victoria Gaol received increasingly large numbers of prisoners. Overcrowding led to deteriorating prison conditions, judged to be 'disgusting'. In 1855, the Chief Magistrate gave a short account of the condition of the gaol, where over a hundred prisoners were huddled together in one room and locked up for the night without any supervision: 'I am told that it was the firm impression on the mind of the late gaoler acquired from his daily opportunities of forming a reliable opinion, that unnatural crime was frequent among the inmates of this ward, and the Sheriff himself does not doubt that it is difficult for a newly-convicted offender to escape being robbed by his fellow-prisoners on the very first night of his transfer to this part of the prison. But be this as it may, the magnitude of the evils that result morally to the young in crime from unrestrained association with scores of hardened criminals, the opportunity which such a state of things must present for the concoction of schemes of villainy to be executed as soon as liberty shall have been regained, are too obvious to require more than a passing note ${ }^{15}$. Two years later, a visiting Justice wrote that the prison was so overcrowded that it was impossible to conduct its routine as it should, while the faulty construction of the buildings and the imperfect means of classification were criticised in 1858 in yet another official report ${ }^{16}$.

8 Cruelty against prisoners was also denounced, leading in one case to the body of a Chinese inmate being ordered exhumed by the Governor: Lye Mooey Chie had been sentenced as a rogue and a vagabond to a term of imprisonment and a couple of floggings. He complained several times of illness and inability to work. He was flogged instead, placed on short rations and put in solitary confinement. The Coroner's jury accompanied their verdict with the comment that an interpreter should be attached to the gaol, further expressing their 'indignation at the cruel usage the deceased met' ${ }^{17}$. The purpose of the prison was to protect the community and to act as a deterrent. Hard labour, as a consequence, was emphasised by the prison authorities, whether productive or non-productive. In the summer of 1850 , for instance, the treadmill was recommended as a form of hard labour and the Justice of Peace requested that the machinery be sent from England to Hong Kong ${ }^{18}$. A report by Colonel Jebb on the benefits of the treadmill was forwarded the following year, as well as information on Fillary's Hardlabour Machine ${ }^{19}$. In 1853, the Government called for tenders for the erection of a treadmill in the prison ${ }^{20}$. Twelve cranks were ordered in 1868 as part of renewed efforts to tighten discipline within the prison ${ }^{21}$. A decade later, the Governor asked about the suitability of the crank as a form of punishment, its mechanical structure and the number of revolutions which should be required within a given time ${ }^{22}$.

10 Chinese prisoners were generally obliged to work in chain-gangs. No sources which would allow the historian to find out how they experienced hard labour are available, although the remaining colonial archives show that many of them suffered from potentially lethal ulcers of the feet and legs. In 1866, for instance, 16 prisoners died out of a total of 281 who were admitted into the Gaol Hospital for the treatment of ulcers (the gaol harboured a total of 4572 Chinese prisoners during the year). According to 
the Colonial Surgeon, those who died had refused to submit to amputation and 'perished from mortification'23.

11 The number of prisoners almost doubled in the late 1850s. A mutiny rocked the prison in 1860 , perhaps the result of sentences considered to be excessively severe ${ }^{24}$. As overcrowding led to deteriorating conditions in the gaol, the government started contemplating the purchase of a convict hulk to be stationed at Stonecutters Island, a scheme proposed by Sir Hercules Robinson. A ship was bought and equipped for this purpose in January $1863^{25}$. In June, the convict hulk Royal Saxon was moored and the island declared a convict station. 280 convicts were examined, pronounced fit for outdoor work and sent on board ${ }^{26}$. A month later, however, thirty-eight prisoners were thrown into the sea when a sampan transporting them to the hulk capsized: all were carried underwater by their chain and drowned. When the hulk was moored closer to the shore to avoid similar tragedies, a hundred dangerous convicts seized the opportunity to escape. The experience was so unsuccessful that the convict establishment was formally discontinued and merged with Victoria Gaol in October 1866 , one year before the completion of improvements to its buildings ${ }^{27}$.

12 Imprisonment, however, was not considered to have any deterrent effect on criminals. The perceived inability of the police to deal with a crime wave in 1865 , moreover, led to renewed demands for a return to the strong deterrent measures initially used by Caine in the early days of the colony ${ }^{28}$. In July 1866 , an ordinance was passed allowing for the branding and flogging of any person who returned to Hong Kong from deportation before the expiration of his sentence ${ }^{29}$. The Colonial Secretary in charge of administering the government until the arrival of Sir Richard MacDonnell (1866-72) in March 1866 also used his authority to pass a new ordinance giving courts the power to flog those convicted of assault with violence. As the Colonial Office in London opposed discriminatory legislation, however, it was soon discovered that Europeans would also be liable to the whip: in one notorious case, John Thompson was sentenced to three years penal servitude and to be three times publicly whipped with the regulation instrument. In the words of James W. Norton-Kyshe, a keen observer of judicial practices in Hong Kong, 'When the lash fell upon the back of the first native, the community felt that the proper methods of dealing with outrageous Chinamen had at last been found, and great satisfaction was expressed at the manner in which the acting Chief Justice applied the law, but this feeling became somewhat checked when it was discovered that it was His Lordship's intention to bring all men alike under the operation of the Ordinance ${ }^{30}$. A petition was accordingly drafted asking for remission, emphasising the 'disgrace' that would attach the European community by the public flogging of one of their members in the presence of the Chinese. The records of the time unfortunately do not show the result of the petition, although the ordinance remained in force throughout the nineteenth century.

The severity of the floggings caused considerable concern among the authorities in England. An inquest, for instance, was held on the body of a prisoner who had died in gaol from the effects of flogging in October 1866. The verdict showed that he had died from the wounds caused by flogging 'legally inflicted' and that hence no blame was attached to anyone ${ }^{31}$. In another case, three gaol wardens were charged two years later with manslaughter through the excessive flogging of an Indian prisoner: a unanimous verdict of not guilty was returned ${ }^{32}$. Sir Richard MacDonnell was instructed by the Colonial Office to forbid any legislation 'whereby persons of African or Asiatic birth 
may be subjected to any disabilities or restrictions to which persons of European birth are not also subjected.' Keen to transform Hong Kong into a model colony by widespread reforms, however, MacDonnell instead simply replaced the rattan cane by the cat and strengthened the earlier ordinance. Where more than two floggings were ordered within six months, the second whipping could, at the discretion of the surgeon, be inflicted within the gaol on the buttocks instead of the back and shoulders ${ }^{33}$. From 1865 to 26 August 1875, the date after which the rattan only was used, over 800 prisoners were illegally flogged with the regulation cat, convicts sometimes being given a greater number of lashes than prescribed ${ }^{34}$.

14 Sir Richard MacDonnell also deported a number of prisoners, on condition that they voluntarily have the lobe of the left ear branded. Branded criminals who returned to the colony were flogged and imprisoned. While MacDonnell succeeded in reducing the number of prisoners, the Colonial office expressed its apprehension over the unduly severe measures and ruled that non-British residents could only be banished if they were dangerous to the peace of the colony. In defence of the system of branding, MacDonnell explained to Carnarvon that it was the only effective mode of preventing criminals from returning to the colony and that he was reluctant to abandon the only 'efficient means of self-defence at our disposal' and thereby expose the colony to a continuance of 'wanton assaults' on property and life. Sixty prisoners had been released by this system in 1866 , and few had returned ${ }^{35}$. Contrary to the impression of the Colonial office, he explained, branding was not perceived as an ignominious punishment but rather as a slight mark which could bring honour as showing that he had been a victim of 'barbarians'. He also disputed the view that branding might prevent a convict from finding work in China ${ }^{36}$. MacDonnell also circumvented a colonial ruling of 1870 and passed an ordinance which allowed a criminal to opt for branding and banishment ${ }^{37}$. The tattooing with Indian ink, according to his successor, was seldom resorted to but worked well ${ }^{38}$. A report on branding made in 1872 by the Superintendent of the Gaol, however, noted that a deported convict with a gaol mark on his neck, which could not be concealed or removed without mutilation, prevented him from obtaining an 'honest livelihood' in his own country, many becoming pirates or robbers near the shores of the colony instead ${ }^{39}$. After 1866, a few dozen men were branded and deported each year until the practice virtually ceased in 1879: the total reached roughly 400 prisoners, a minority in comparison to the much greater number of gaol sentences ${ }^{40}$.

15 A Gaol Committee completed a review of Victoria Gaol in 1876: in its report, submitted to the Governor Arthur Kennedy, the committee spelt out that 'the primary object of punishment is to deter from crime.' The report further argued that 'Owing to the peculiar circumstances of this Colony, and the fact that by far the larger proportion of the criminals confined in the Gaol are Chinese, whose language is but little known to those who have charge of them, whose characters and dispositions are imperfectly understood, and of whose previous history and lives it is almost impossible to obtain any knowledge, any attempt to cultivate their higher faculties and to improve their moral condition seems hopeless' ${ }^{41}$. The committee recommended more use of the crank as well as the continued use of shot drill, oakum picking, stone carrying, and stone breaking for its deterrent effect on prisoners. 


\section{'Stone and shot': the redemptive virtue of prison labour, 1877-1898}

16 The various tensions which existed between proponents of equal treatment and supporters of discriminatory practices on the one hand and between deterrent penal policies and a reformative approach on the other came to full expression under Pope Hennessy. Sir John Pope Hennessy (1877-1882), the new Governor appointed in 1877, was described by contemporaries as a 'restless spirit' 'wanting in common sense' who displayed sympathy for the underdog. Colonial administrators often moved through a number of different countries and transmitted models and preferences from one place to another: Hennessy had served several years as governor of Labuan, the Gold Coast and the Windward Islands, apparently clashing with colonial communities by taking into account local predilections. Contrary to his predecessors, he made it an official policy to consult with the Chinese community, an approach which was profoundly resented by colonial administrators ${ }^{42}$. Soon after arriving on the island, he tackled the question of corporal punishment and ordered an investigation into the administration of the prison. Contrary to his predecessors, he emphasised the need for reformation in the treatment of criminals. The prison, according to Pope Hennessy, was 'the great engine by which crime should be stamped out': it had failed to fulfil its promise as crime had seriously increased in the year leading to his appointment. The report of the Gaol Committee, however, had clearly expressed its reluctance to even envisage reformation as a gaol of confinement. The abandonment of any hope of reformation, in the view of Hennessy, was a dangerous departure of the 'sound principles of prison discipline' which had been laid down in every part of the empire, namely that confinement should consist of a 'due mixture of severe punishment with some attempt at reformation': any deviation from these principles could only result in the lamentable results which could be witnessed in Hong Kong ${ }^{43}$.

17 Hennessy was horrified to discover that prisoners were released without any consideration for their conduct in prison after having served only one-third of their sentences with a view to relieve overcrowding in the prison rather than to benefit the 'honest community' outside. He used the 1872 report on branding to question its effectiveness in reducing the number of prisoners in gaol, noting that a sample of 39 prisoners branded and deported in January included long sentenced prisoners, short sentenced prisoners, prisoners whose characteristics were described as 'very bad' as well as ones being considered as 'very good', all being sent in a batch to the mainland when one third of their sentence had been worked out. Hennessy singled out the example of a prisoner named Wong A Ling, sentenced to three months but branded and deported after only one month: as the acting Superintendent did not speak a word of Chinese, he wondered whether he could not have been mistaken in reporting that the prisoner was willing to be disfigured and marked as a thief for the rest of his life. The forms which the prisoners were asked to sign, moreover, were in English which few could read ${ }^{44}$.

18 A few months later, Hennessy also brought the case of Chun Afook to the attention of Lord Carnarvon: the prisoner had been six times in gaol, having returned from deportation on three separate occasions ${ }^{45}$. Further evidence suggested that branded criminals gathered in the gambling haunts in the villages just beyond the boundary of Kowloon, some presumably committing the night robberies which had pestered the 
colony over the last years ${ }^{46}$. A system of repeated short sentences on old offenders was a bad system, Hennessy argued in front of the Legislative Council, as it created and cultivated a criminal class. The most fundamental penal principles, namely (1) the separation of young offenders from adult criminals by placing the former in a reformatory establishment; (2) the enforcement of the separate system amongst adults; (3) the establishment of penal labour by treadmill, crank, shot drill, or similar means; (4) and the moral and industrial training of those prisoners whose sentences were long enough to have an effect on their 'future disposition and mode of life', were all blatantly disregarded in Hong Kong. Turnkeys, moreover, were not only unable to speak the language of the prisoners, having abandoned all hope to improve their moral condition, but were found guilty of drunkenness in the gaol and beating prisoners: Hennessy proposed to fill the vacancies created by dismissals with well-conducted warders who could speak Chinese as well as a number of native turnkeys ${ }^{47}$. Hennessy refused to allow any further deportations, making an exception in the case of two prisoners in 1878 who were dying: he sent them to the hospital instead. He noted that many Europeans wanted a revival of the earlier days before his arrival when many prisoners were branded, flogged and deported ${ }^{48}$. A final report on deportation was compiled in 1879, recommending that it should be confined to habitual offenders in addition, rather than as a substitution, of a custodial sentence ${ }^{49}$.

If knowledge about criminals was considered to be an essential part of the prison's redemptive mission, medical knowledge was also given great prominence by Sir John Pope Hennessy. In Singapore, for instance, a penal diet had been introduced in 1875 without due regard for the opposition of the colonial surgeon. A riot ensued which resulted in the death of a prison officer, as, according to Hennessy, it was not merely the physical condition of a prisoner which was affected by his treatment in prison, but his mind as well: he could be rendered 'a fierce, desperate, irreclaimable man'. In Hong Kong, medical knowledge indicated that Orientals differed from Europeans in their physiological responses to flogging: a slight blow could sometimes kill a native when it might not even injure a European. According to Dr Ayres, the Colonial Surgeon consulted by Hennessy, Chinese prisoners flogged with the cat had symptoms of congestion of the lungs, many ending up in the hospital spitting blood, while the scars on their backs remained for the rest of their lives ${ }^{50}$. In his report prepared at the request of Hennessy, Dr Ayres observed that in India flogging was always performed on the breech with a four-foot rattan ('as thick as a man's forefinger'). Thanks to their 'more powerful build' and 'greater muscularity', he explained, Europeans were less prone to injury from the cat than the Chinese ${ }^{51}$. He suggested that flogging be administered on the breech and not on the back, as ex-convicts would feel shame at the indelible gaol marks on that part of the body ${ }^{52}$. Hennessy reluctantly allowed a few cases of flogging after he assumed government in Hong Kong, although he recollected that not a single lash was applied in Singapore and Labuan during his four years there, while flogging had also ceased in the Bahamas ${ }^{53}$.

The shift from punitive punishment towards a more redemptive approach heralded by Pope Hennessy with the support of the Colonial office encountered widespread opposition in Hong Kong. Both proponents and opponents of penal reform, however, invoked alleged cultural and 'racial' differences between Europeans and Chinese to justify their arguments. Sir John Smale, the Chief Justice, thus commented: 'I am bound to state that although I have ever considered the punishment brutal, and brutalizing, unfit for a large, high-grade, civilized community, practical results have brought me, 
most unwillingly, to the conviction, that for a country where the criminal classes are far less humanized, flogging is practically useful, especially in such a Colony as this, imbedded, as it were, in an Empire where Draconian laws prevail, and crimes, subjecting here to flogging, are punished by the most horrible tortures and by death ${ }^{54}$. Such opinions were widespread in Hong Kong. Charles May, First Police Magistrate, wrote in his report that corporal punishment was both fitting and needful to the treatment of Chinese criminals. He considered the gap between the 'cruel and oppressive character' of Chinese gaol management to be in such marked contrast to imprisonment in the Victoria Gaol that some other form of punishment was a necessity to the colony: 'It can readily be understood that imprisonment with hard labour in the Gaol of Victoria, wherein the prisoner is better fed, better and cleanlier clothed, better lodged and less worked (inasmuch as he has rest on the Sabbath) than the honest artizan or labourer, would scarcely operate as a prevention of crime, and this more especially when such imprisonment carries with it very little of the shame and disgrace attaching it, as in England.' Flogging, on the other hand, was held in wholesome dread, and seemed the only efficacious method of restraining crime: the withdrawal of this method, he was convinced, would greatly increase crime and the necessity for an enlarged gaol ${ }^{55}$. Sir Edmund Hornby, the late Chief Justice of the Supreme Court for China and Japan, also wrote to underline that 'it requires a very stiff upper lip and the exercise of most unpleasant firmness to maintain proper discipline amongst the ruffians who by accident, rather than by the hand of justice, find their way into Hongkong Gaol.' Experience of twenty years, he added, had convinced him that corporal punishment was a necessary evil ${ }^{56}$. Deplored the China Mail: 'The old days when an offending cook would be corrected, perhaps with a leg of mutton he had spoiled, or the concussive application of the right boot to that portion of the human body on which our Colonial Surgeon insists the Oriental should be flogged, are gone ${ }^{57}$. The Hong Kong Daily Press also called for the renewal of flogging and its 'salutary effects $^{58}$.

21 Even Dr Ayres' analysis of the effects of flogging were questioned by local administrators who opposed penal reform. A medical committee, appointed in 1879 to find out whether flogging on the back produced phthisis, failed to find sufficient evidence to uphold the conclusions offered in the report. Gaol congestion and lack of fresh air was deemed to be as great a contributory cause as the cat, and the committee suggested that "the punishment of flogging on the back with the "regulation cat», without any knots, be continued; care being taken by means of a thick canvas collar that the neck is not injured and that the loins be protected in a similar way so that by these means the blows should fall on the muscles covering the shoulder blades and the intermediate spinal space. That flogging on the back not be inflicted on any person under eighteen years of age. That flogging on the breech with six tails of the cat be the punishment of offenders from the age of thirteen to eighteen, and the «birch» be used for offenders of more tender years ${ }^{\prime 59}$. The committee also considered the rattan to be too heavy a weapon, as its effects 'go deep into the cellular and muscular tissues, producing a loss of substance by sloughing' ${ }^{\prime 60}$.

Sir John Hennessy nonetheless adhered to a new system he had put in place since June 1878, when prisoners were whipped on the breech with a rattan ${ }^{61}$. He argued that the physical condition of the Chinese differed from Europeans, a physiological fact which was acknowledged by the Chinese government over a thousand years ago, as flogging never took place on the back because it would lead to injury to the viscera. Hennessy 
also invoked the existence of local ordinances which unequivocally prescribed the rattan and the desire of the home government to abolish the cat ${ }^{62}$. Reactions from the European community were swift: a public meeting was convened on 7 October 1878 to discuss the unusual activity of the criminal classes and the general feeling of insecurity, as it was suspected that the undue leniency of the governor, especially the suspension of public flogging, the substitution of the rattan on the breech in lieu of the cat-o'-ninetails and a more cautious use of deportation, was its cause. Speeches in support of the resolutions were summarised in the words of A.P. MacEwen: 'Let the Magistrates, instead of inflicting paltry fines of 10 cents or short term of imprisonment, have the power to inflict summary chastisements on all rogues and vagabonds. Let them be taken from the Magistry and publicly flogged at the whipping-post' ${ }^{\prime 63}$. The Home Office, however, backed Pope Hennessy's approach. In July 1880, the Secretary of State approved his recommendations on the treatment of criminals in Hong Kong. The Earl of Kimberly specifically noted that he "entertained grave objections on general grounds to the infliction of the punishment in question and especially to that of flogging for ordinary offences' ${ }^{64}$.

While Sir John Pope Hennessy was opposed to branding, flogging and deportation, he believed that the dietary scales used in the prison were far too generous. After surprise visits to the prison, and from his knowledge of the average meal of a "hard working Chinese coolie' outside the prison, he cut down the dietary scale and introduced a different diet for Europeans as part of a deterrent policy ${ }^{65}$. Hennessy appealed to the principle of less eligibility, according to which prisoners should not live and work in better conditions than those prevalent outside the prison walls, to justify reduced portions of food; he also pointed at the need for remunerative hard labour, a fundamental aspect of prison discipline which could act as a deterrent against crime.

Much greater emphasis on the prison as a moral space of reformation led to the appointment of Alex Gordon as Superintendent of Victoria Gaol in 1885. Although Hennessy's plan for the construction of a prison with separate cells had to be dropped in view of widespread opposition, the arrival of Gordon led to an overhaul of the prison rules and regulations which brought prison discipline in line with practices in force in England. Remission of sentence became dependent on conduct and industry assessed under a mark system, while the silence system was enforced throughout the prison to prevent any communication between prisoners. Prisoners were required to work from six to ten hours daily, the different types of labour to which they were assigned comprising shot drill, stone carrying, crank labour, oakum picking, washing clothes, making coir and public works ${ }^{66}$. Although the main objective of hard labour was to 'reform criminals to habits of industry' ${ }^{67}$, a commission appointed in 1886 to consider the problem of overcrowding in Victoria Gaol concluded that the regime imposed on all prisoners was still to liberal: 'A short detention, say under six months, is no punishment for an ordinary Chinaman, he is better fed and better housed in prison than outside and the work or task which he has to perform is certainly less than he would have to do to obtain a livelihood were he free'68. The principle of less eligibility was used again to maintain differential treatment. The diet for Chinese prisoners was reduced in the following years and convicts sentenced to terms of one year or more with hard labour were fettered with weights of 3 pounds, secured to an iron ring on each ankle with a chain suspended by a hook from the waist belt ${ }^{69}$. A large number of prisoners struck work in the gaol in order to protest the decreased supply of pork 
under the new regime. Fifty-four prisoners were flogged, receiving twelve strokes each with the rattan, a case which was subsequently discussed in Parliament in May $1887^{70}$.

Physical punishment, hard labour and the silence system continued to dominate penal practice well until the end of the nineteenth century. As late as in 1893, moreover, as Victoria Gaol was enlarged and improved to implement the separate system, strong opposition was voiced by prominent politicians who believed that banishment and the rattan would be a better alternative in order 'to make the prisoners' life not so much a life of ease as it is at present ${ }^{71}$. The China Mail echoed these reservations, applauding the use of whips for 'impudent' cases of robbery the same year, considered to be a form of punishment which the majority of residents would like to see inflicted more frequently to reduce crime: 'At this season of the year many a Chinaman would not mind stealing if he had the certainty of being caught and of luxuriating in the comfortable quarters provided in Victoria Gaol': salutary punishment in the shape of the rattan would have a more deterrent effect $^{72}$. Members of the Chinese community also feared that the separate system was a 'paradise for rascals' which would fail to inspire fear and lead to an increase of crime ${ }^{73}$. The Legislative Council nonetheless approved funds for the extension of the prison, an illustration of the tension between official measures to implement penal reform and the popular demand for tough measures against criminals.

\section{Conclusion}

Hong Kong was widely regarded throughout the nineteenth century as a colonial enclave in which the lash and the rattan were used far more frequently than in any other part of the world. The custodial sentence became more common only during the last third of the nineteenth century and never entirely superseded corporal punishment. A variety of punishments were used against criminals by the colonial authorities as Hong Kong grew into a thriving trading port during the first decades after its establishment in 1841. Transportation, imprisonment, the use of the prison hulk, flogging, banishment and branding were all tried by successive governors concerned with the maintenance of social order in a rapidly growing island perceived to be overrun with criminals from the mainland. These different approaches were based on a deterrent policy and differential treatment aimed to prevent crime rather than to reform offenders. As imprisonment gradually emerged as the only viable alternative to transportation and flogging, the principle of less eligibility was used in providing prisoners with hard labour and hard fare: even in prison, however, European and Chinese prisoners were given a different penal diet and different types of hard labour. The idea of moral reformation was introduced only by the end of the 1870 s by an unpopular governor with the backing of London against colonial authorities and European communities in Hong Kong. While the custodial sentence became the principal penalty used against offenders, local elites resisted the construction of a prison based on the separate system: a new prison with individual cells - hallmark of the reformative approach current in Europe - would only appear in 1936 with support from the Colonial Office. The abandonment of flogging in prison, on the other hand, was delayed for several decades after World War II due to lack of popular support from both European and Chinese communities. In 1946, Downing Street noted that corporal punishment had no deterrent effect and that the important differences between Britain 
and the colonies were not consistent with the principles of 'racial equality"74. Although the cat was outlawed in the colony in July 1948 (a sample was kept as a museum piece at the Staff Training School at Stanley $)^{75}$, the cane continued to be used on juvenile and adult prisoners for several decades ${ }^{76}$. In an investigation of corporal punishment in 1965, various opinions from the public showed that over 65 per cent favoured the retention of corporal punishment. Hundreds of letters from members of the Chinese community in particular indicated a widespread belief in the deterrent value of the cane $^{77}$. Even after Hong Kong's handover to China in 1997, local communities continue to underline the need for differential treatment of criminals from the mainland, the reflection of a deeply entrenched distrust of the principle of equal treatment which has characterised the island from the very moment it was ceded to Britain.

\section{BIBLIOGRAPHY}

Chan, S. Development of the Hong Kong penal policy and programme under the British Administration (1841-1945), Hong Kong, School of Professional and Continuing Education, University of Hong Kong, MA dissertation, 1994.

Crisswell, C., Watson, M., The Royal Hong Kong Police (1845-1945), Hong Kong, Macmillan, 1982.

Dikötter, F., Crime, Punishment and the Prison in Modern China, London, Hurst, New York, Columbia University Press, 2002.

Garland, D., Punishment and Modern Society: A Study in Social Theory, Oxford, Clarendon, 1990.

Norton-Kyshe, The History of the Laws and Courts of Hong Kong, Hong Kong, Vetch and Lee, 1971

(orig. 1898), 2 volumes.

Welsh, F., A Borrowed Place: The History of Hong Kong, New York, Kodansha International, 1993.

\section{NOTES}

2. Garland (1990, pp. 268-270).

3. Crisswell, Watson (1982, p. 11).

4. Norton-Kyshe (1971, orig. 1898, vol. 1, p. 31).

5. Norton-Kyshe (1971, vol. 1, pp. 107-108).

6. Norton-Kyshe (1971, vol. 1, pp. 131-132).

7. Crisswell,Watson (1982, p. 27).

8. Norton-Kyshe (1971, vol. 2, p. 84).

9. Norton-Kyshe (1971, vol. 2, p. 188).

10. Norton-Kyshe (1971, vol. 1, pp. 141-142).

11. Blue Book, 1846, pp. 234-241; see also Norton-Kyshe (1971, vol. 1, p. 31).

12. Chan, 1994 (pp. 19-20).

13. Norton-Kyshe (1971, vol. 1, p. 301).

14. Norton-Kyshe, 1971 (vol. 1, p. 440). 
15. Norton-Kyshe (1971, vol. 1, p. 644).

16. Ibid.

17. Norton-Kyshe (1971,vol. 1, p. 645).

18. CO 129/33, 5 July 1850 , pp. 151-159.

19. CO 129/38, 14 March 1851, pp. 201-144.

20. Norton-Kyshe (1971, vol. 1, p. 333).

21. CO 129/130, 29 May 1868, pp. 129-130.

22. CO 129/177, 28 March 1877, p. 384.

23. Hongkong Government Gazette, 23 March 1867, p. 99.

24. Norton-Kyshe (1971, vol. 1, p. 643).

25. CO 129/91, 14 Feb. 1863, pp. 185-208.

26. Norton-Kyshe (1971, vol. 2, p. 52).

27. CO 129/116, 23 Nov. 1866, pp. 105-135.

28. Crisswell, Watson (1982, p. 45).

29. Hongkong Government Gazette, 28 July 1866, p. 301.

30. Norton-Kyshe (1971, vol. 2, p. 157).

31. Norton-Kyshe (1971, vol. 2, pp. 93-94).

32. Norton-Kyshe (1971, vol. 2, p. 47).

33. CO 129/184, 28 May 1879, pp. 477-478; on the adoption of the regulation cat, see also CO 129/106, 8 Aug. 1865, pp. 34-35.

34. CO 129/185, 8 Nov. 1879, p. 420.

35. CO 129/120, 14 Jan. 1867, pp. 122b-123a.

36. CO 129/121, 29 April 1867, pp. 390-391.

37. Crisswell, Watson (1982, pp. 52-54).

38. Crisswell, Watson (1982, p. 58).

39. CO 129/178, 12 July 1877 , pp. 363 b.

40. C0129/184, 29 April 1879, p. 190.

41. CO129/177, 28 Feb. 1877, p. 176.

42. Welsh (1993, pp. 255-256).

43. Hongkong Government Gazette, 22 Sept. 1877, p. 411.

44. CO 129/178, 12 July 1877, pp. 362-371.

45. CO 129/179, 20 Sept. 1877, p. 145.

46. C0129/179, 25 Oct. 1877, pp. 270-271.

47. Hongkong Government Gazette, 22 Sept. 1877, pp. 411-412.

48. CO 129/184, 29 April 1879, pp. 194 and 200.

49. CO 129/184, 29 April 1879, pp. 188-189.

50. Hongkong Government Gazette, 22 Sept. 1877, pp. 413-414.

51. Norton-Kyshe (1971, vol. 2, pp. 263-264).

52. Hongkong Government Gazette, 12 Nov. 1879, p. 675.

53. Hongkong Government Gazette, 22 Sept. 1877, p. 414.

54. Norton-Kyshe (1971, vol. 2, pp. 263-264).

55. CO 129/182, 3 Jan. 1878, p. 188b.

56. Norton-Kyshe (1971, vol. 2, pp. 265-266).

57. China Mail, 30 May 1878.

58. Hong Kong Daily Press, 3 Sept. 1878.

59. Hongkong Government Gazette, 4 June 1879, p. 296.

60. Hongkong Government Gazette, 12 Nov. 1879, p. 674.

61. Norton-Kyshe (1971, vol. 2, p. 295).

62. Hongkong Government Gazette, 4 June 1879, p. 295.

63. Hongkong Government Gazette, 17 Sept. 1879, p. 536. 
64. Norton-Kyshe (1971, vol. 2, p. 314).

65. CO 129/182, 3 Oct. 1878, pp. 194-195.

66. Blue Book, 1887, p. X3; Hongkong Government Gazette, 21 Nov. 1885, pp. 1017-1034.

67. Hongkong Government Gazette, 3 April 1886, p. 269.

68. Chan (1994, p. 63).

69. Hongkong Government Gazette, 15 Jan. 1887, p. 39; 22 June 1889, p. 522.

70. CO 129/231, 1 Feb. 1887, pp. 101-107.

71. Hong Kong Sessional Paper, no. 1/93, p. 71.

72. China Mail, 5 Jan. 1893.

73. Hongkong Government Gazette, 28 Jan. 1893, p. 57.

74. HKRS, $125 / 3 / 464$, p. 3 .

75. HKRS, 70/1/452(119).

76. HKRS, 41/1/4234, p. 46; see also HKRS, 41/1/4241, p. 2.

77. HKRS, $424 / 1 / 23$, p. 4.

\section{ABSTRACTS}

Hong Kong was widely regarded as a colonial enclave in which the lash and the rattan were used far more frequently than in any other part of the world. This article shows that the custodial sentence never entirely superseded corporal punishment: the idea that legal sanctions should deter rather than reform was widespread among both European and Chinese communities in Hong Kong, and both favoured a punitive approach towards the criminal. Prisoners were initially locked up together in common cells while awaiting transportation, a practice which became more common as practical problems prevented the use of existing modes of punishment, in particular transportation, branding and the use of a hulk ship. This article analyses the gradual transformation of the prison from a site of deterrence to a place of reformation in the nineteenth century.

Hong Kong était généralement considérée comme une enclave coloniale où le fouet et le rotin étaient beaucoup plus fréquemment employés que partout au monde. Cet article montre que l'emprisonnement ne prit jamais complètement le pas sur les châtiments corporels. L'idée selon laquelle la sanction pénale devait dissuader plutôt qu'amender était très répandue parmi les Européens et les Chinois de Hong Kong, et les deux groupes étaient favorables à une attitude punitive à l'égard des criminels. Initialement, les prisonniers étaient encellulés collectivement dans l'attente de leur transportation; cette pratique se répandit lorsque des difficultés pratiques prévinrent l'utilisation des châtiments habituels, comme la transportation, la marque et l'emploi de bateaux-prisons. Cet article analyse la transformation graduelle de la prison, au XIX ${ }^{\mathrm{e}}$ siècle, de lieu de dissuasion qu'elle était, en lieu d'amendement. 


\section{AUTHOR}

\section{FRANK DIKÖTTER}

Professor of the Modern History of China, School of Oriental and African Studies, University of London, Thornhaugh Street, London WC1H OXG, UK, fd3@soas.ac.uk

Frank Dikötter is Professor of the Modern History of China at the School of Oriental and African Studies, University of London. The author would like to thank Phillip Bruce and Samson Chan. He has published several books on racial identity, sexuality and eugenics in modern China. His Crime, Punishment and the Prison in modern China appeared in 2002 (Columbia), and his examination of the opium myth was published as Narcotic Culture: A History of Drugs in China in 2004 (Chicago). He is currently leading a project on the global history of the prison and working on a history of material culture and things modern in China. 